\title{
Bullying (Perundungan) di Lingkungan Pendidikan Kedokteran
}

Anna Rozaliyani ${ }^{\mathrm{I}, 2}$, Broto Wasisto ${ }^{\mathrm{I}}$, Frans Santosa ${ }^{\mathrm{I}, 3}, \mathrm{R}$ Sjamsuhidajat ${ }^{\mathrm{I}}$, Rianto Setiabudy ${ }^{\mathrm{I}, 4}$,

Pukovisa Prawiroharjo ${ }^{\mathrm{I}, 5}$, Muhammad Baharudin ${ }^{1}$, Ali Sulaiman

${ }^{ }$Majelis Kehormatan Etik Kedokteran Pengurus Besar Ikatan Dokter Indonesia

${ }^{2}$ Departemen Parasitologi, Fakultas Kedokteran Universitas Indonesia

${ }^{3}$ Fakultas Kedokteran Universitas Pembangunan Nasional Veteran Jakarta

${ }^{4}$ Departemen Farmakologi Fakultas Kedokteran Universitas Indonesia, Jakarta

'Departemen Neurologi, Fakultas Kedokteran Universitas Indonesia/Rumah Sakit Cipto Mangunkusumo

\section{Kata Kunci}

Peserta pendidikan kedokteran, perundungan

\section{Korespondensi}

annarozaııı@gmail.com

Publikasi

(C) 2019 JEKI/ilmiah.id

\section{DOI}

I0.26880/jeki.v3i2.36

Tanggal masuk: 13 Agustus 2019

Tanggal ditelaah: 16 Oktober 2019

Tanggal diterima: I9 November 2019

Tanggal publikasi: 30 Desember 2019
Abstrak Dalam lingkungan pendidikan kedokteran, bullyingatau perundungan masih kerap terjadi. Korban perundungan umumnya peserta didik atau junior, sedangkan pelaku perundungan antara lain pendidik dan senior. Perundungan merupakan bentuk pelanggaran etik dasar dan hak asasi manusia, yang dapat berdampak buruk terhadap peserta didik, lingkungan kerja, maupun kualitas pelayanan kesehatan. Untuk itu diperlukan upaya komprehensif dengan menyertakan berbagai pihak terkait guna mencegah dan menghentikannya. Perbaikan kurikulum pendidikan yang mengutamakan prinsip kesetaraan dan etika kesejawatan, diharapkan dapat mencegah dan menghentikan tindakan perundungan secara bertahap dan sistematis.

Abstract In medical education, bullying or harassment still often occurs. Victims of harassment are generally students or juniors, while the perpetrators may be educators and seniors. Harassment is a form of violation of basic ethics and human rights, which can adversely affect students, work environment, as well as the quality of health services. A comprehensive effort is required to prevent and stop it, by involving various related parties. Improvement of education curriculum that prioritizes the principle of equality and ethics is expected to prevent and stop acts of bullying in a gradual and systematic manner.

Bullying, dalam Bahasa Indonesia dikenal dengan istilah perundungan, umumnya terjadi di lingkungan sekolah dan dialami anakanak. Pada kenyataannya, perundungan dapat terjadi di berbagai bidang kehidupan, mulai dari lingkungan sekolah hingga lingkungan profesi. Di dunia pendidikan kedokteran, berbagai bentuk perundungan masih kerap terjadi, yang paling sering adalah dalam bentuk verbal, biasanya berupa perintah, misalnya perintah pembelian kebutuhan material untuk kepentingan pribadi perundung (senior).

Perundungan di lingkungan pendidikan kedokteran belum terdokumentasi dengan baik, meskipun hal itu dirasakan nyata ada. Sayangnya, tindakan tersebut seolah dianggap sebagai kebiasaan yang dapat dibenarkan, sehingga terundung sulit menyatakannya. Terundung dan saksi mata pun biasanya lebih memilih bungkam. ${ }^{1}$ Perundungan jelas berkaitan dengan pelanggaran etik dasar khususnya asas autonomy dan non-maleficence terhadap terundung, serta potensi pelanggaran justice terhadap kelompok berisiko seperti terundung. Artikel ini ditujukan untuk membahas masalah perundungan di lingkungan pendidikan kedokteran yang merugikan berbagai pihak, serta mencari solusi terbaik untuk mencegah dan menghentikan perundungan itu.

\section{Definisi perundungan}

Bullying atau merundung menurut Kamus Besar Bahasa Indonesia berarti menyakiti orang lain, baik secara fisik maupun psikis, 
dalam bentuk kekerasan verbal, sosial, atau fisik berulang kali dan dari waktu ke waktu, misalnya memanggil nama seseorang dengan julukan yang tidak disukai, memukul, mendorong, menyebarkan rumor, mengancam, atau merongrong. ${ }^{2}$ Perundungan adalah suatu tindakan penggunaan kekuasaan untuk menyakiti seseorang atau sekelompok orang, baik secara verbal, fisik, maupun psikologis, sehingga korban merasa tertekan, trauma, dan tak berdaya. ${ }^{3}$

Perundungan di dunia kedokteran diibaratkan sebagai penyakit kronik, kebiasaan lama yang sulit dihentikan. Peserta didik junior, residen, dan sejawat perempuan merupakan pihak yang rentan mengalami perundungan. ${ }^{4}$ Hal itu terjadi karena pihak institusi maupun asosiasi profesi tidak mampu memberikan perlindungan memadai kepada terundung, sulit menerima perubahan, dan cenderung menganggap perundungan sebagai suatu kebiasaan yang sulit terelakkan. ${ }^{5}$

Perundungan seakan menjadi hidden curriculum (kurikulum tersembunyi) dalam pendidikan kedokteran. Perilaku buruk tersebut dapat mengganggu komunikasi dan hubungan interpersonal serta berdampak negatif pada kualitas pelayanan pasien.

\section{Pihak yang terlibat dalam perundungan}

Secara umum, perundungan melibatkan pelaku (perundung) yang biasanya memiliki sifat psikososial buruk, pihak korban (terundung) yang dapat mengalami gejala depresi, serta pihak lain yang tidak terlibat dalam perilaku agresif (netral). ${ }^{3}$ Perundung terkadang tidak menyadari bahwa mereka telah melakukan tindakan yang tidak terpuji itu. ${ }^{6}$

Perundungan di dunia kedokteran dapat melibatkan tenaga pendidik, residen, perawat, dan mahasiswa. Pada umumnya korban perundungan adalah mahasiswa kedokteran, termasuk peserta pendidikan dokter spesialis (PPDS), teman sejawat perempuan serta lulusan asing atau internasional. Pelaku perundungan umumnya adalah dokter senior atau pemilik otoritas. $^{5}$
Peserta didik junior rentan mengalami perundungan karena seniornya menyalahgunakan kewenangan yang diberikan kepadanya. ${ }^{4,7}$ Survei terkait perundungan yang diikuti 594 anggota British Medical Association menunjukkan 220 orang pernah mengalami perundungan pada masa sebelumnya. ${ }^{8}$ Survei pada 833 dokter residen di Kanada menunjukkan lebih dari $75 \%$ residen pernah menerima perilaku tidak pantas selama proses pendidikan. Sebanyak $77,1 \%$ residen pernah mengalami tindakan perundungan oleh pasien; $55,3 \%$ oleh paramedis; $51,9 \%$ oleh staf medis; $35,7 \%$ oleh residen lain dan 7,6\% oleh pengelola program studi. Perilaku tidak pantas tersebut paling banyak dialami oleh residen bedah $(85,7 \%)$ dan paling sedikit oleh residen kedokteran keluarga $(69,5) .{ }^{9}$

Di lingkungan mahasiswa kedokteran, persepsi perilaku tidak pantas itu dianggap sebagai suatu pendekatan untuk meningkatkan kualitas pendidikan. ${ }^{10}$ Penelitian pada 2.300 mahasiswa di 16 sekolah kedokteran menunjukkan $85 \%$ mahasiswa pernah mengalami tindakan kekerasan atau pelecehan, sedangkan $40 \%$ mahasiswa mengalami kedua perlakuan buruk itu. Dalam penelitian tersebut tidak ditemukan pengaruh faktor etnis maupun jenis kelamin. Perundungan terhadap mahasiswa kedokteran dapat dilakukan oleh mahasiswa lain maupun pasien, tetapi selama ini residen dan tenaga pendidik yang sering disalahkan. Sebanyak 13\% mahasiswa mengaku pernah mendapat perlakuan perundungan berat. $^{?}$

\section{Bentuk perundungan}

Bentuk perundungan dapat berupa perilaku kekerasan meliputi pemaksaan, baik fisik maupun psikologis terhadap seseorang atau sekelompok orang yang lebih lemah. ${ }^{3}$ Perundungan dan perilaku kekerasan itu dapat berupa ancaman terhadap kelangsungan pendidikannya, ancaman terhadap martabat/ harga diri, isolasi, beban kerja berlebih, dan pengaruh terhadap kepercayaan diri terundung. Pada umumnya kebiasaan merundung berlangsung terus menerus, semakin buruk, dan merugikan. ${ }^{7}$ Kebiasaan buruk tersebut 
berakibat pada gangguan kestabilan psikologi terundung dalam hal kemampuannya di masa depan, pilihan karir, dan kemauannya untuk bertahan dalam profesi tersebut. Perundungan dapat mencakup berbagai aspek: kekerasan fisik, verbal, relasional, dan cyber. Kekerasan fisik dapat berupa pukulan, cekikan, dan tindakan lain yang umumnya mudah dideteksi. Kekerasan verbal dapat berbentuk julukan, celaan, dan fitnah, serta pernyataan tak pantas terkait masalah seksual. Kekerasan relasional biasanya menargetkan harga diri korban, sehingga sulit terdeteksi. Kekerasan cyber merupakan tindakan perundungan yang memanfaatkan teknologi, internet, dan media sosial. ${ }^{3}$

Dalam dunia pendidikan kedokteran, perundungan dapat berupa tindakan pelemparan barang, mengecilkan pendapat residen, teriakan, ancaman, dan komentar yang tidak pantas. ${ }^{11}$ Selain bentuk perundungan yang nyata, terdapat bentuk lain yang lebih kecil, misalnya nada bicara sinis dan penolakan saran-saran. ${ }^{1}$ Perundungan biasanya dilakukan oleh senior atau pengajar terhadap peserta didik junior. Hal itu dikaitkan dengan struktur hierarki tradisional dan konservatif dalam pendidikan kedokteran, sehingga muncul suatu siklus kekerasan. Peserta didik mendapat perlakuan tidak pantas dalam perjalanannya menjadi seorang dokter. Siklus kekerasan itu menjadi kurikulum tersembunyi yang diwariskan dari generasi ke generasi, selanjutnya berkembang menjadi perundungan yang berbasis penyalahgunaan wewenang.

\section{Latar belakang terjadinya perundungan}

Perubahan yang cepat dan luas di dunia pendidikan kedokteran dianggap menjadi alasan pembenaran tindakan perundungan. Perubahan itu mencakup berkembangnya ilmu pengetahuan dan teknologi kedokteran modern, serta perubahan harapan pasien dan berkembangnya pengetahuan pasien tentang kualitas pelayanan. Mahasiswa kedokteran dituntut untuk terus mengikuti kemajuan zaman. Untuk itu, pendidik berusaha menyelenggarakan program pendidikan dasar, kemampuan dan sikap demi menciptakan kualitas peserta didik yang baik. Dalam proses pendidikan itu dapat terjadi tindakan perundungan sebagai suatu kurikulum tersembunyi.?

\section{Kaitan perundungan di lingkungan pendidikan dengan hak asasi manusia}

Undang-Undang nomor 39 tahun 1999 pasal 33 ayat 1 menyatakan: "Setiap orang berhak untuk bebas dari penyiksaan, penghukuman, atau perlakuan yang kejam, tidak manusiawi, merendahkan derajat dan martabat kemanusiaannya." 12 Sementara itu, dalam Universal Declaration of Human Rights pasal 26 ayat 2, dinyatakan bahwa "Education shall be directed to the full development of the human personality and to the strengthening of respect for human rights and fundamental freedoms, ....".13 Berdasarkan deklarasi hak asasi manusia, pendidikan seharusnya membuat seorang individu berkembang dengan selalu mengutamakan rasa hormat. Untuk itu, selain berhak mendapatkan ilmu dari pendidik, setiap peserta didik berhak mendapatkan perlindungan dan rasa aman dari berbagai bentuk perundungan di lingkungan pendidikan. Hal tersebut merupakan salah satu hak asasi manusia yang fundamental. Dengan demikian, perundungan merupakan salah satu bentuk pelanggaran terhadap hak asasi manusia. $^{14}$

\section{Akibat perundungan terhadap korban}

Tidak semua korban perundungan menunjukkan perubahan psikologis sebagai respons terhadap perlakuan buruk yang dialaminya. Sebagian terundung menganggap bahwa perlakuan tak menyenangkan yang mereka alami merupakan upaya meningkatkan kualitas kompetensi dan kemampuan beradaptasi di dunia kerja. ${ }^{7}$

Dalam kenyataannya, tindakan perundungan ini dalam banyak kasus bersifat persisten dan dapat menimbulkan gangguan psikologis terhadap korban, serta dapat mempengaruhi kinerja masa depan, pilihan karir, dan kemampuan bertahan di profesi tersebut. ${ }^{10}$ Beberapa terundung mengalami trauma dan dampak negatif, seperti alkoholisme, depresi, upaya bunuh diri, dan kekecewaan terhadap profesi dokter yang 
menjadi pilihannya. ${ }^{7}$ Terdapat dampak negatif berupa penurunan kemampuan kognitif sebesar $60 \%$, serta penurunan koordinasi psikomotor. ${ }^{6}$

\section{Upaya bersama dalam peristiwa perundungan di dunia kedokteran}

Tidak mudah mencegah perundungan di lingkungan kerja profesional. Pembiaran terhadap tindakan perundungan di dunia profesional akan berdampak buruk terhadap perkembangan profesi itu sendiri. Anggapan bahwa perundungan merupakan bagian dari kebiasaan merupakan hal yang berbahaya. Di sisi lain, kebiasaan yang sudah mengakar tersebut bukan berarti juga tidak dapat diubah. ${ }^{6}$ Untuk itu diperlukan intervensi mendasar berupa kebijakan institusi yang menciptakan lingkungan kerja nyaman dengan memperkecil peluang terjadinya perundungan. ${ }^{7}$ Upaya lain mencakup peningkatan kesadaran setiap individu agar tidak terlibat dalam perundungan, melawan segala bentuk perundungan, serta memberikan dukungan kepada pihak terundung. ${ }^{15}$

Institusi pendidikan kedokteran memiliki peran strategis dalam upaya mencegah dan menghentikan perundungan di kalangan peserta didik. Upaya tersebut dapat dilakukan melalui perbaikan kurikulum khususnya dalam hal sosial-emosional, dimulai dengan mengedukasi para staf pengajar dan seluruh sivitas akademika tentang paradigma kesetaraan dalam pendidikan dan etika kesejawatan. Bahaya perundungan terhadap pembentukan kebiasaan dan moral peserta didik, serta dampak buruknya terhadap kualitas pelayanan kesehatan harus mendapatkan perhatian serius. Para staf pengajar dan senior hendaknya menjadi role model (teladan) dalam upaya menghentikan perilaku tidak pantas itu. Penyelesaian kasus perundungan secara komprehensif dengan menyertakan semua pihak terkait harus dilakukan dengan penuh kesungguhan. Upaya menyediakan sarana khusus untuk melaporkan kasus perundungan secara rahasia dan aman, perlindungan terhadap saksi yang melaporkan kasus perundungan, serta pemberian sanksi yang tegas dan objektif terhadap setiap pelaku perundungan juga harus dilaksanakan secara konsisten. Berbagai upaya tersebut akan lebih berhasil dan terasa manfaatnya apabila dilaksanakan secara menyeluruh dan disepakati oleh semua institusi pendidikan kedokteran. Dalam hal ini Asosiasi Institusi Pendidikan Kedokteran Indonesia (AIPKI) bersama-sama dengan Kolegium Kedokteran Indonesia (KKI) memiliki peran strategis dalam menetapkan kebijakan nasional untuk mengatasi perundungan di lingkungan pendidikan kedokteran.

Dalam organisasi profesi kedokteran di Indonesia, Majelis Kehormatan Etik Kedokteran (MKEK) memiliki peran penting dalam mencegah dan mengatasi pelanggaran etik terkait perundungan. Bekerja sama dengan institusi pendidikan kedokteran, MKEK dapat menginisiasi perbaikan kurikulum pendidikan dengan memasukkan nilai-nilai etik dasar dan penerapannya secara bertahap, sistematis, dengan mempertimbangkan perkembangan situasi terkini. Sejak awal masa pendidikan, hendaknya setiap peserta didik diperkenalkan dengan nilai-nilai etik dasar beneficence, nonmaleficence, autonomy, dan justice. Prinsip kesetaraan dalam proses pendidikan dengan tetap mengedepankan kesantunan, tanggung jawab, integritas, dan etika kesejawatan harus terus-menerus diingatkan kepada seluruh peserta didik. Hal itu sejalan dengan Kode Etik Kedokteran Indonesia (KODEKI), khususnya tentang Kewajiban Umum (pasal 1-4, dan 9-10), Kewajiban Dokter terhadap Teman Sejawat (pasal 18-19). Selain itu MKEK bekerjasama dengan Dewan Etik Perhimpunan Dokter Spesialis/profesi juga berperan penting dalam upaya pencegahan dan penghentian tindakan perundungan, khususnya dalam lingkungan pendidikan dan profesi dokter spesialis yang bersangkutan. Kerja sama tersebut hendaknya juga diperkuat dengan melakukan koordinasi dengan institusi lain di luar profesi maupun pendidikan kedokteran. Dengan demikian kebijakan yang ditetapkan dapat berjalan selaras demi kepentingan bersama, khususnya dalam upaya meningkatkan kualitas pelayanan kesehatan bagi masyarakat. 


\section{KESIMPULAN}

Perundungan di dunia pendidikan kedokteran masih kerap terjadi, terutama dilakukan terhadap peserta didik junior. Pada kenyataannya, perundungan merupakan pelanggaran terhadap hak asasi manusia dan nilai-nilai etik dasar. Untuk itu, upaya mengatasi perundungan harus dilakukan terus-menerus, berupa intervensi institusi pendidikan dalam hal perbaikan kurikulum, menciptakan lingkungan kerja aman dan nyaman, serta memperkuat kesadaran setiap individu untuk menghentikannya. Selain itu kerja sama antarlembaga terkait juga diperlukan dalam penetapan kebijakan yang selaras demi kepentingan bersama.

\section{KONFLIK KEPENTINGAN}

Penulis tidak memiliki konflik kepentingan dalam penulisan artikel ini.

\section{REFERENSI}

1. Medical disrespect. [internet] Aeon. 29 januari 2014 [disitasi pada 12 Januari 2019]. Dapat diakses melalui: https://aeon.co/ essays/bullying-junior-medical-staff-is-oneway-to-harm-patients

2. Kamus Besar Bahasa Indonesia.

3. Zakiya EZ, Humaedi S, Santoso MB. Faktor yang mempengaruhi remaja dalam melakukan bullying. Jurnal Penelitian dan PPM 2017:4(2):324. https://doi. org/10.24198/jppm.v4i2.14352

4. Vogel L. Doctors dissect medicine's bullying problem. CMAJ 2017. 189(36). E1661-2. https://doi.org/10.1503/cmaj.1095484

5. I am a medical student, and I am afraid to report bullying and harassment. Australian Medical Student Journal 2016.

6. Bullying: no longer acceptable in a noble profession [Internet]. BMJ. 14 februari 2014 [disitasi pada 12 Januari 2019]. Dapat diakses melalui: https://www.bma.org.uk/ news/2018/february/undermining-bullying

7. Wood DF. Bullying and harassment in medical school. BMJ 2006;333(7570):6645. https://doi.org/10.1136/ bmj.38954.568148.BE

8. Quine L. Workplace bullying in junior doctors: questionnaire survey. BMJ 2002;324:878. https://doi.org/10.1136/ bmj.324.7342.878

9. Vogel L. Canadian medical residents report pervasive harassment, crushing workloads. CMAJ 2018 November 19;190:E1371. https://doi.org/10.1503/cmaj.109-5678

10. Major A, MBA. To Bully and Be Bullied: Harassment and Mistreatment in Medical Education. Virtual Mentor. 2014;16(3):155160. https://doi.org/10.1001/virtualmento r.2014.16.3.fred1-1403

11. Vogel L. Bullying still rife in medical training. CMAJ 2016;188(5):321-2. https:// doi.org/10.1503/cmaj.109-5237

12. Undang-Undang Republik Indonesia nomor 39 tahun 1999 tentang Hak Asasi Manusia.

13. Universal Declaration of Human Rights United Nations 1948.

14. US Department of Health and Human Services. Bullying: A human rights issue. PrevNet

15. Promoting human rights education in the classroom. Rights Sites News 2010. 6(4):1-11. 